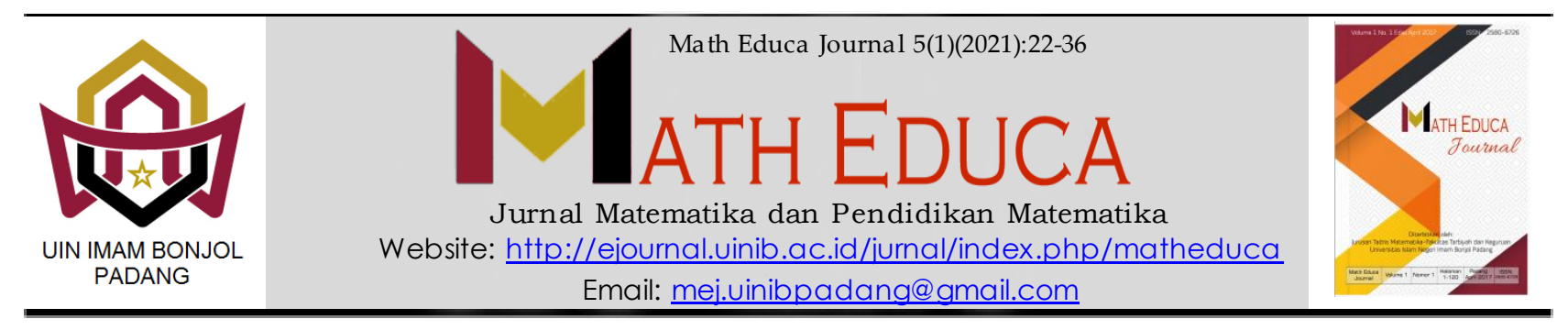

\title{
ANALISIS KEMAMPUAN CALON GURU MATEMATIKA DALAM MEMBUAT SOAL PEMECAHAN MASALAH MATEMATIKA
}

\author{
${ }^{1}$ Ali Umar*, ${ }^{2}$ Nur Ainun Lubis, ${ }^{3}$ Nurul Qomariyah Ahmad, ${ }^{4}$ Edy Saputra , ${ }^{5}$ Mustafa Kamal \\ Nasution \\ 1,2,3,4Tadris Matematika, IAIN Takengon, 5PGMI, IAIN Takengon
}

E-mail: 1panghuluraj086@gmail.com, 22ainunlubis123@gmail.com, ${ }^{3}$ gomariyahnrl@gmail.com, ${ }^{4}$ edysaputra.esa@gmail.com, 5 kamalnasution@gmail.com.

Received: February 2021; Accepted: March 2021; Published: April 2021

\begin{abstract}
Problem solving is the main focus in learning mathematics at the primary and secondary school level. Prospective teachers must be prepared as well as possible as problem solvers and problem solving instructors. The purpose of this study was to describe the prospective teacher's ability to make a problem solving question based on category of good mathematical problem solving questions. The type of research used is descriptive qualitative. The research subjects were students of semester VI of the 2019/2020 academic year of the IAIN Takengon Mathematics Education Study Program. Based on the research results, it shows that the subjects in general already understood the theory of problem solving, but this understanding did not always directly proportional to the ability to make a mathematical problem solving question.
\end{abstract}

Keyword: Prospective teacher's ability, mathematical problem solving questions

\section{Abstrak}

Pemecahan masalah menjadi fokus utama dalam pembelajaran matematika di tingkat sekolah dasar dan menengah.Para calon guru harus dipersiapkan dengan matang sebagai pemecah masalah dan pengajar pemecahan masalah. Tujuan dari penelitian ini adalah untuk mendeskripsikan kemampuan calon guru dalam membuat soal pemecahan masalah berdasarkan kategori soal pemecahan masalah matematika yang baik.Jenis penelitian yang digunakan adalah deskriptif kualitatif.Subjek penelitian adalah mahasiswa semester VI TA 2019/2020 Prodi Tadris matematika IAIN Takengon.Teknik pengumpulan data menggunakan studi dokumen dan wawancara. Berdasarkan hasil penelitian menunjukan bahwa subjek secara umum sudah memahami teori tentang soal pemecahan masalah namun pemahaman tersebut tidak selalu berbanding lurus dengan kemampuan dalam membuat soal pemecahan masalah.

Kata kunci: Kemampuan calon guru, soal pemecahan masalah matematika

\footnotetext{
${ }^{*}$ Corresponding author.

Peer review under responsibility UIN Imam Bonjol Padang.

(C) 2021 UIN Imam Bonjol Padang. All rights reserved.

p-ISSN: $2580-6726$

e-ISSN: $2598-2133$
} 


\section{PENDAHULUAN}

Fokus utama dalam pembelajaran matematika adalah agar siswa memiliki kemampuan memecahkan masalah(L. Lestari \& Sofyan, 2014). Menurut $\operatorname{NCTM(2000)}$ pemecahan masalah menjadi salah satu standar dalam pembelajaran matematika.Belajar matematika adalah belajar untuk memecahkan masalah(Samo, 2017). Siswa dapat membangun pengetahuan baru melalui pembelajaran pemecahan masalah(Demirel et al., 2015; H. Lestari et al., 2020).Oleh karena itu pemecahan masalah baik sebagai proses maupun tujuan menjadi bagian yang sangat penting dalam pembelajaran matematika.

Di Indonesia, pemberlakuan kurikulum 2013 mengharuskan pembelajaran matematika menggunakan pendekatan saintifik agar siswa dapat menggunakan pengetahuan yang dimiliki untuk memecahkan masalah(Permendikbud, 2014). Pemecahan masalah juga telah menjadi perhatian utama dalam pendidikan diberbagai negara(Lutfianto et al., 2012). Namun sampai sejauh ini kompetensi siswa dalam pemecahan masalah matematikadi Indonesia masih berada pada level yang belum menggembirakan. Hasil tes yang dikeluarkan PISA (Programme for International Student Assessment) tahun 2018 memposisikan peringkat literasi matematika siswa Indonesia berada pada posisi 71 dari 77 negara peserta (Schleicher, 2018). Posisi tersebut berada di bawah negara-negara ASEAN kecuali Filipina yang berada posisi 76 . Sementara itu hasil tes TIMSS ( Trend In International Matematics and Science Study) tahun 2015 menempatkan Indonesia pada posisi 44 dari 49 negara peserta(Mullis et al., 2015).Hal ini juga diperkuat dengan rata-rata hasil Ujian Nasional matematika tingkat SMP dan SMA tahun 2019 yang memberikan porsi soal dengan level kognitif yang lebih tinggi (termasuk pemecahan masalah matematika) sekitar 10-15\% tidak mencapai skor 50 dari 100(Kemendikbud RI, 2020). Oleh karena itu sangat dibutuhkan berbagai usaha agar kemampuan matematika siswa di Indonesia menjadi lebih baik, salah satunya kemampuan pemecahan masalah matematika.

Agar siswa menjadi pemecah masalah yang baik, dibutuhkan kemampuan guru dalam memecahkan masalah dan mengajarkan pemecahan masalah(Chapman, 2015). Beberapa penelitian menunjukan bahwa kemampuan pemecahan masalah calon guru dapat ditingkatkan dengan berbagai model pembelajaran(Ningsih \& Purwasih, 2017; Oktaviyanthi \& Agus, 2018; Purnomo \& Mawarsari, 2014).

Namun guru ataupun calon guru yang mempunyai kemampuan kategori baik dalam memecahkan masalah matematika belum tentu mahir juga dalam mengajarkan 
pemecahan masalah matematika.Sebab, kemampuan memecahkan masalah terdapat pada ranah kemahiran sedangkan mengajarkan pemecahan masalah terlatak pada pengetahuan tentang merancang dan memilih masalah (Chapman, 2015). Kami mensurvey pengalaman guru dalam merancang masalah dan menemukan data bahwa hanya 10 dari 27 guru matematika SMP di kabupaten Aceh Tengah yang pernah membuat soal pemecahan masalah. Temuan ini juga sejalan dengan beberapa penelitian yang menemukan bahwa kemampuan guru dalam merancang soal pemecahan masalah masih kurang(Febrilia, 2019; Hidayah et al., 2014). Selain itu para mahasiswa yang melakukan validasi soal pemecahan masalah kepada kami ditemukan bahwa soal-soal tersebut belum termasuk kategori soal pemecahan masalah matematika.

Sangat penting bagi guru menjadi ahli dalam merancang masalah untuk siswa.Akses internet yang semakin mudah membuat soalsoal pemecahan masalah di buku ajar menjadi soal-soal biasa karena sudah banyak yang membahasnya secara online.Bahkan soal-soal PISA yang sudah diujikan sangat mudah ditemukan pembahasannya di internet. Sebagai contoh soal PISA 2018 bisa di akses pembahasannya link https://www.youtube.com/watch?v=BZfelzPYi 60. Hal ini tentu sangat membantu siswa dalam belajar, namun jika soal tersebut diberikan kepada siswa sebagai tugas rumah kemudian siswa menjawab hanya dengan mencontoh penyelesaian tanpa memikirkannya maka penilaian kemampuan siswa menjadi tidak tepat. Alasan lain adalah agar kemampuan pemecahan masalah bisa diakses dengan benar dibutuhkan soal yang mampu mengukur kemampuan pemecahan masalah yang valid. Disamping itu, guru menjadi individu yang paling tahu tentang kondisi siswa di dalam kelas. Setiap siswa mempunyai kemampuan yang berbeda dalam menyelesaikan masalah(Youngchim et al., 2015). Oleh karena itu membuat soal pemecahan masalah sesuai dengan kondisi siswa merupakan sebuah keharusan.

Dalam pembelajaran matematika, sebuah soal dikatakan masalah ketika seseorang ingin menyelesaikannya namun dia tidak langsung menemukan prosedur untuk memecahkan soal tersebut(Bell, 1978; Cahyani \& Setyawati, 2016; Kurniawan, 2016; Reiss \& Törner, 2007; Schoenfeld, 1987; Schunk, 2012).Munculnya keinginan dari siswa untuk menyelesaikan soal pemecahan masalah karena soal tersebut belum mereka dapatkan sebelumnya sehingga mereka tertantang untuk menyelesaikannya. Namun, walaupun sebuah soal yang belum pernah diberikan kepada siswa tetapi mereka langsung menemukan prosedur untuk menyelesaikannya maka soal tersebut tidak 
termasuksoalpemecahan masalah(Schoenfeld, 1987; Suherman dkk, 2002).

Berdasarkan beberapa pengertian masalah yang diberikan para ahli, maka soalsoal matematika yang melibatkan perhitungan rumit seperti angka-angka besar atau bilangan berkoma sementara siswa memahami dengan cepat prosedur penyelesaiannya dan hanya terkendala pada rumitnya perhitungan bukan dikategorikan sebagai masalah. Selain itu, terkendalanya siswa dalam memahami soal yang diberikan karena bahasa yang tidak jelas, bermakna ganda atau informasi dan istilah yang belum diketahui oleh siswa bukan merupakan ciri-ciri sebuah soal bertipe masalah.Sebuah soal yang baik harus terlepas dari kesalahan berbahasa yang berdampak negatif kepada peserta didik dalam memahami dan menjawab soal(Wardani et al., n.d.). Bahasa soal harus ringkas, padat dan sesuai ejaan yang berlaku(Siswono, 2018)

Sementara itu, menurut Polya (1973) soal pemecahan masalah bisa diselesaikan dengan menggunakan empat langkah penyelesaian yaitu memahami masalah; merencanakan dan memilih strategi;melaksanakan rencana tersebut dan melihat kembali. Keempat langkah penyelesaian ini bisa dilaksanakan dengan soal-soal yang membutuhkan pemikiran, menimbulkan tantangan; prosedur yang belum diketahui dan dapat diselesaikan pada tingkat kogntif siswa yang diberikan soal tersebut.

Berdasarkan pengertian masalah dan langkah penyelesaiannya menurut para ahli, maka karakteristik soal yang digunakan dalam menganalis soal pemecahan masalah dalam penelitian ini adalah

a. Soal tersebut menggunakan bahasa yang baik dan benar sehingga tidak menimbulkan makna ganda; istilah-istilah yang diberikan dalam soal adalah istilah yang dipahami oleh siswa;

b. Siswa tidak bisa langsung menemukan prosedur penyelesaian soal tersebut;

c. Soal tersebut menimbulkan tantangan untuk diselesaikan oleh siswa;

d. Soal pemecahan masalah tidak melibatkan perhitungan yang rumit seperti angkaangka yang besar atau bilangan-bilangan berkoma yang sulit dilakukan operasi secara manual;

e. Penyelesaian soal pemecahan masalah membutuhkan pengetahuan-pengetahuan yang sudah didapatkan oleh siswa sebelumnya;

f. Soal yang diberikan kepada siswa tidak sama dengan soal yang diberikan sebelumnya (non rutin). Dalam hal ini, sebuah soal pemecahan masalah hanya dengan mengganti angka atau merubah konteks namun dengan model 
penyelesaian yang sama bukan merupakan soal pemecahan masalah.

g. Soal pemecahan masalah membutuhkan lebih dari satu langkah penyelesaian.

h. Dapat berupa soal open ended, dapat berupa soal dengan banyak cara penyelesaian atau banyak jawaban.

Karena begitu pentingnya keterampilan dalam merancang sebuah soal pemecahan masalah matematika maka para calon guru yang sedang belajar di perguruan tinggi harus meningkatkan kemampuan mereka.Penelitian ini bertujuan untuk menganalisis kemampuan calon guru dalam membuat sebuah soal dengan tipe pemecahan masalah.Diharapkan hasil penelitian ini bermanfaat sebagai tambahan data untuk meningkatkan kualitas calon guru matematika dan penelitian lebih lanjut.

\section{METODE PENELITIAN}

\section{Jenis Penelitian}

Jenis penelitian yang digunakanadalah deskriptif kualitatif dengantujuan untuk mendeskripsikan kemampuan calon guru dalam membuat soal pemecahan masalah.

\section{Waktu dan Tempat Penelitian}

Penelitian di laksanakan pada bulan September2020 di IAIN Takengon.

\section{Subjek Penelitian}

Subjek penelitian diambil dari mahasiswa semester VIITadris Matematika tahun akademik 2020/2021berjumlah 10 orang.Subjek tersebut dipilih karena mereka sudah mendapatkan mata kuliah Kapita Selekta Matematika dan Strategi Pembelajaran Matematka serta akan mengadakan PPL (Praktek pengalaman Lapangan) pada bulan November 2020.

\section{Prosedur}

Penelitian dilakukan dengan memberikan tugas kepada subjek berupa membuat sebuah soal matematika tipe pemecahan masalah untuk siswa tingkat SMP dengan materi tabung dan konteks kehidupan sehari-hari.Subjek diminta menyelesaikan soal tersebut dalam satu minggu.Berhubung sedang pandemi Covid 19 di wilayah penelitian, maka tugas tersebut disebar dan dikumpul melalui aplikasi Whatsapp.Tugas yang dikumpulkan subjek kemudian dianalisis menggunakan indikator soal pemecahan masalah yang baik, setelah itu dilakukan wawancara mengenai soal yang subjek buat.

\section{Teknik Pengumpulan data}

Data yang dikumpulan adalah data primer berupa dokumentasi soal yang dibuat oleh subjek dan hasil wawancara dengan subjek.Soal yang dikumpulkan subjek dibuat dengan tulisan tangan. Soal tersebut 
kemudian disalin tanpa perubahan ke microsoft word sementara gambar pada soal disalin dengan aplikasi geogebra. Tujuan penyalinan ini agar soal menghemat tempat dan gambar lebih presisi yang memudahkan analisis.Sedangkan wawancara dilakukan dengan menggunakan telepon yang direkam agar lebih memudahkan analisis hasil wawancara tersebut.

\section{Teknik Analisis Data}

Soal pemecahan masalah yang dibuat subjek dikumpulkan untuk dianalisis lebih lanjut.Analisis soal dibatasi hanya pada konstruksi soal yang dibuat subjek dengan berpedoman kepada karakteristik soal pemecahan masalah yang baik.Setelah soal dianalisis kemudian dilakukan wawancara dengan subjek mengenai soal yang dibuat dan pemahaman subjek tentang soal pemecahan masalah matematika.

Sehubungan dengan jenis penelitian ini merupakan penelitian kualitatif maka validasi digunakan untuk memastikan akurasi informasi yang didapatkan dari subjek (Hamzah, 2019). Validasi dokumen soal dilakukan dengan memastikan bahwa subjek memahami dengan tepat perintah pada isntrumen. Sedangkan validasi wawancara dilakukan dengan merekam hasil wawancara dan menuliskannya dikertas kemudian mengkonfirmasi kembali kepada subjek jika

ditemukan hasil rekaman yang bermakna ganda.

\section{HASIL PENELITIAN DAN PEMBAHASAN}

Instrumen penelitian disebarkan pada bulan November 2020 melalui aplikasi whatsapp.Subjek diberikan waktu untuk menyelesaikan tugas yang ada di instrumen dalam waktu 7 hari.Setelah itu subjek diminta untuk mengirimkan tugas tersebut melalui pesan whatsapp.Dari 10 subjek yang dikirimkan instrumen ada 6 subjek yang mengembalikan instrumen kepada peneliti

Ke-6 soal yang dikirimkan subjek kemudian dianalisis.Setelah soal dianalisis kemudian dilakukan wawancara melalui telepon dengan subjek pemilik soal tersebut.

\section{Soal Subjek 1}

Berikut soal pemecahan masalah dan alternatif jawaban yang dibuat subjek 1

Andi ingin mengadakan pesta di rumahnya. Dia acara tersebut Andi menyediakan berbagai makanan dan minuman, namum persediaan menuman Andi ternyata telah habis. Andi terpaksa harus pergi membeli minuman ke toko yang biasa Andi kunjungi. Disana Andi mendapati 2 jenis minuman yang sama namun berbeda ukuran

Jenis A

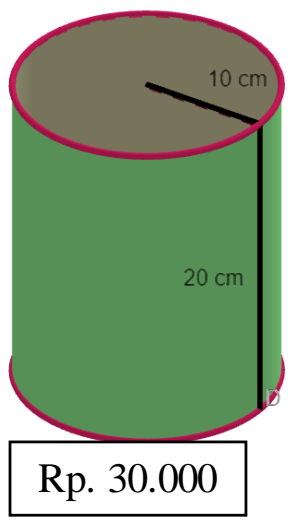

Jenis B

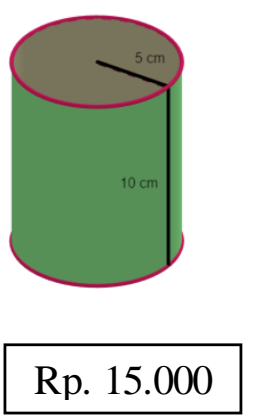


Jenis minuman manakah yang seharusnya Andi beli agar menguntungkan jika Andi mempunyai uang Rp. 30.000

$$
\begin{aligned}
& V=\pi r^{2} \cdot t \\
= & \frac{22}{7} 10^{2} \cdot 20 \\
& \frac{22}{7} 100 \cdot 20 \\
= & 6.285,7142 \\
& V=\pi r^{2} \cdot t \\
= & \frac{22}{7} 5^{2} \cdot 10 \\
= & \frac{22}{7} 25 \cdot 10 \\
= & \frac{550}{7} \cdot 10 \times 2 \text { botol } \\
= & 1.571,4285
\end{aligned}
$$

Jadi untukmendapatkan keuntungan yang lebih Andi harus membeli minuman jenis $A$ yaitu 1 botol dengan harga Rp. 30.000

Materi dan konteks soal yang dibuat oleh subjek 1 sudah sesuai dengan yang diminta dalam instrumen.Subjek membuat soal dengan materi tabung dengan konteks cerita kehidupan sehari-hari.

Bahasa yang digunakan subjek 1 sudah jelas dan tidak memiliki makna ganda. Istilah, notasi dan angka yang dalam soal sudah dikenali oleh siswa tingkat SMP.Hal ini sudah sesuai dengan kategori soal yang bisa digunakan.

Masalah yang diangkat di dalam soal termasuk permasalahan nonrutin.Asumsinya adalah, bahwa dalam pembelajaran didalam kelas para guru terlebih dahulu mengenalkan konsep luas dan volume tabung.Soal-soal rutin biasanya berisi pertanyaan tentang luas dan volume.Sementara pada soal yang dibuat subjek 1 lebih komplek, tidak terlihat bahwa soal tersebut mencari volume tabung yang diberikan.Siswa harus memahami terlebih dahulu permasalahan dan pertanyaan yang diberikan soal. Berdasarkan aspek kenonrutinanmaka soal yang dibuat oleh subjek 1 sudah termasuk soal pemecahan masalah.

Alternatif jawaban yang diberikan oleh subjek 1 terlihat sederhana karena hanya memasukan informasi kedalam rumus. Namun sebelum sampai ke tahap tersebut, dibutuhkan beberapa langkah penyelesaian seperti pemahaman, perencanaan baru kemudian eksekusi soal. Dengan kata lain, soal tersebut membutuhkan lebih dari satu langkah penyelesaian. Aspek ini merupakan salah satu ciri soal pemecahan masalah.

Setelah dilakukan analisis, kemudian peneliti melakukan wawancara dengan subjek untuk triangulasi data.Berdasarkan wawancara, menurut subjek soal pemecahan masalah sudah pasti berbeda dengan soal-soal umum, soal pemecahan masalah tidak bisa langsung dijawab sebab tidak terlalu terfokus pada penggunaan rumus akan tetapi membutuhkan keteletian dan analisis terhadap permasalahan yang diberikan.Subjek 1 menyatakan bahwa orang yang hapal rumus belum tentu bisa menyelesaikan soal pemecahan masalah, biasanya siswa yang hapal rumus tanpa memahami tidak bisa menyelesaikan soal yang berubah bentuk dari contoh sebelumnya.

Hasil wawancara tersebut juga sebanding dengan hasil analisis soal yang dibuat oleh Subjek 1. Dapat diambil kesimpulan bahwa pengetahuan kemampuan subjek 
dalam membuat pemecahan masalah berbanding lurus dengan pengetahuannya terhadap soal pemecahan masalah.

\section{Soal Subjek 2}

Berikut soal pemecahan masalah dan alternatif jawaban yang dibuat subjek 2

Suatu hari ibu membeli aquarium berbentuk tabung tanpa tutup dengan diameter alasnya $20 \mathrm{~cm}$. sesampai di rumah lbu mengisi air kedalam aquarium dengan penuh sebanyak 6,28 L. Tidak lama kemudian Dina pulang sekolah dan melihat aquarium yang dibelikan ibunya berbentuk tabung dan itu mengingatkan Dina dengan pembelajaran matematika yang baru saja dia pelajari hari ini. Sehingga membuat dia ingin menghitung berapa luas permukaan aquarium tersebut. Dan ditengah pemecahan masalah yang dikerjakan oleh dina, Dina kebingungan dikarenakan aquarium tersebut tidak memiliki tutup yang mengartikan aquarium tersebut hanya memiliki satu lingkaran saja. Sekarang coba bantu dina untuk menyelesaikan permasalahan tersebut

\section{Diketahui:}

Diameter Aquarium $=20 \mathrm{~cm}=$ jari $=10 \mathrm{~cm}$ Volume Aquarium $=6,28$ liter $=6280 \mathrm{~cm}^{3}$ Ditanya : Luas Permukaan aquarium Volume tabung $=\pi r^{2} \cdot t$

$6280 \mathrm{~cm}^{3}=3,14 \times 10 \times 10 \times t$

$6280=314 t$

$\frac{6280}{314}=t$

$20=t$

Luas permukaan aquarium = luas selimut + luas alas

$$
\begin{aligned}
& =2 \pi r t+\pi r^{2} \\
=2(3,14) \times 10 \times 20+ & (3,14) \times 10^{2} \\
& =1256+314 \\
& =1570
\end{aligned}
$$

Jadi, luas permukaan aquarium tanpa tutup adalah $1570 \mathrm{~cm}$

Bahasa soal yang digunakan subjek 2 sudah jelas dan tidak bermakna ganda.Narasi soal dibuat dengan baik sehingga informasi yang disampaikan dalam soal bisa dipahami siswa.Angk-angka yang digunakan dalam soal mudah untuk dilakukan operasi hitung manual, notasi soal seperti $\mathrm{cm}$ dan $\mathrm{L}$ adalah notasi yang sudah dikenali oleh siswa.jadi soal sudah bisa diterima dari segi bahasa, angka, istilah mapun notasi.

Materi soal sudah sesuai dengan yang diminta di instrumen.Sementara konteks soal yang digunakan oleh subjek 2 adalah permasalahan kehidupan sehari-hari dengan benda yang sudah dikenali oleh siswa.Jadi secara materi dan konteks soal tersebut bisa dianalisis lebih lanjut.

Dari segi permasalahan, soal tersebut belum termasuk soal pemecahan masalah.Pertanyaan yang diberikan masih berfokus pada pertanyaan yang digunakan untuk mengukur pemahaman konsep siswa. Siswa yang memahami konsep volume dan luas tabung akan dengan mudah mengenali prosedur penyelesaian soal tersebut. Hal ini bertentangan dengan ciri soal sebuah masalah dimana prosedur soal tidak bisa diketahui dengan cepat(Reiss \& Törner, 2007).

Dalam menyelesaikan soal tersebut, siswa tidak terlalu membutuhkan pengetahuan-pengetahuan yang sudah didapatkan sebelumnya. Penyelesaian soal bisa dengan satu langkah dengan cara memasukan informasi yang ada kedalam 
rumus dan melakukan operasi hitung. Hal ini bukan merupakan ciri dari soal pemecahan masalah matematika.

Hasil wawancara dengan subjek 2 menunjukan subjek tersebut memahami teori tentang soal pemecahan masalah dengan sukup baik.Subjek menerangkan bahwa soal pemecahan masalah adalah soal yang membutuhkan pemahaman dalam menyelesaikannya, soal tersebut biasanya berbentuk soal ceritadan dalam menyelesaikannya membutuhkan pemahaman tentang konsep pada materi soal tersebut. Namun pemahaman subjek tersebut belum sebanding dengan contoh soal yang dibuat

\section{Soal Subjek 3}

Berikut soal pemecahan masalah dan alternatif jawaban yang dibuat subjek 3

Nabila memiliki 3 buah kaleng bekas biskuit yang sama besar dengan ukuran $d=21 \mathrm{~cm}$ dan $t=30 \mathrm{~cm}$. Nabila ingin membungkus kain kaleng tersebut menggunakan kain flanel agar tampak lebih menarik untuk digunakan sebagai celengen. Berapa minimal luas kain flanel yang dibutuhkan Nabila untuk membungkus ketiga kaleng tersebut?

Jawab

Diketahui

$d=21 \mathrm{~cm} \rightarrow r=10,5 \mathrm{~cm}$

$t=30 \mathrm{~cm}$

$\pi=3,14$

Ditany $a=$ luas minimal flanel $=.$. .

Penyelesaian:

Luas minimal flanel = luas permukaan ketiga

kaleng. Jadi

$L p=2 \pi r(r+t)$

$=2.3,14 \cdot 10.5(10,5+30)$

$=65,94(40,5)$

$=2670,57 \mathrm{~cm}^{2}$
Karena ketiga kaleng Nabila memiliki ukuran yang sama, maka Lp nya pun sama. Jadi Lp total $=2670,57 \times 3=8011,71 \mathrm{~cm}^{2}$

Jadi Nabila harus memiliki kain flanel dengan ukuran luas minimal $8011,71 \mathrm{~cm}^{2}$ untuk membungkus ketiga kaleng bekas miliknya

Soal yang dibuat Subjek 3 bisa dibaca dengan jelas dan tidak bermakna ganda.Istilah yang digunakan dalam soal sudah dikenali oleh siswa.Angka-angka pada soal bisa dilakukan operasi matematika secara manual.Dengan demikian kesulitan soal karena penggunaan bahasa, istilah yang tidak diketahui maupun operasi hitung yang sulit sudah bisa dihindarkan dalam menyelesaikan soal tersebut.

Subjek 3 menggunakan materi dan konteks yang diminta dalam isntrumen.Materi yang digunakan adalah tabung sedangkan konteks yang digunakan adalah permasalahan kehidupan sehari-hari. Cerita soal bisa dibayangkan dan sudah dikenali oleh siswa.Jadi berdasarkan materi dan konteks soal tersebut sudah memenuhi syarat untuk dianalisis.

Berdasarkan aspek ke-nonrutinan, soal tersebut sudah termasuk soal pemecahan masalah. Prosedur soal tidak akan mudah ditemui oleh siswa yang baru belajar konsep volume dan luas tabung. Dibutuhkan pengetahuan lain seperti perbandingan dan luas bidang datar untuk menyelesaikan soal tersebut. Soal tersebut cukup menantang siswa karena berbeda dengan soal pemahaman konsep pada umumnya. 
Dari segi cara penyelesaian, soal tersebut bisa dikerjakan dengan lebih dari satu cara. Siswa bisa menyelesaikan dengan cara mencari masing-masing luas kain flanel untuk satu celengan atau mencari luas kain flanel untuk ketiga celengan tersebut. Hal ini merupakan salah satu dari ciri soal pemecahan masalah.

Pemahaman Subjek 3 terhadap soal pemecahan masalah matematika cukup baik.berdasarkan wawancara Subjek 3 mengemukakan bahwa soal pemecahan masalah biasanya berbentuk soal cerita, tidak bisa langsung ditemukan cara penyelesaiannya, bisa diselesaikan dengan banyak cara dengan hasil yang tetap sama. Pemahaman subjek 3 tersebut sesuai dengan ciri soal pemecahan masalah kecuali pada aspek cara penyelesaian. Soal pemecahan masalah bisa berupa soal dengan banyak cara penyelesaian dan banyak jawaban, yang dikenal dengan soal open ended(Siswono, 2018).

\section{Soal Subjek 4}

Berikut soal pemecahan masalahmatematika dan alternatif jawaban yang dibuat oleh subjek 4 .

Sebuah perusahaan ingin membuat penampungan air berbentuk tabung menggunakan plat besi. Penampungan air yang dibuat dapat terisi air sebanyak $942 \mathrm{dm}^{3}$. Dengan jari-jari $10 \mathrm{dm}$ dan $\pi=3,14$. Makan tentukanlah luas plat besi yang dapat digunakan untuk membuat selimut tabung?
Penyelesaian

Dik:

$V=942 d m^{3}$

$r=10 \mathrm{dm}$

$\pi=3,14$

Dit: Luas selimut tabung....?

$\Rightarrow$ mencari tinggi tabung $(t)$

$V_{\text {tabung }}=\pi \cdot r^{2} \cdot t$

$942=3,14 \cdot 10.10 . t$

$942: 314=t$

$3=t$

Sehingga luas selimut tabung

$=2 . \pi \cdot r \cdot t$

$=2.3,14.10 .3$

$=188,4 \mathrm{dm}^{3}$

Soal tersebut bergategori baik berdasarkan aspek bahasa, istilah, notasi dan penggunaan angkaNamun dari segi permasalahan yang diberikan soal tersebut belum termasuk soal pemecahan masalah matematika.Kategori soal masih soaluntuk mengukur pemahaman konsep siswa.Siswa yang memahami konsep volume dan luas tabung akan dengan mudah menemukanprosedur penyelesaian soal tersebut sehingga soal tersebut tidak menimbulkan tantangan yang cukup menarik bagi siswa. Berdasarkan langkah penyelesaian, soal tersebut bisa diselesaikan hanya dengan memasukan informasi ke dalam rumus.

Berdasarkan wawancara, menurut Subjek 4 soal tersebut termasuk soal pemecahan masalah karena berbentuk soal cerita.Selain berbentuk soal cerita, Subjek 4 mengemukan bahwa perbedaan soal tersebut 
dengan soal yang bukan masalah terletak pada pertanyaan dan informasi yang diberikan.Soal biasa selalu menanyakan langsung kepada volume atau luas tabung sementara informasi seperti jari-jari sudah diberikan langsung, sehingga siswa cukup memasukan informasi ke rumus.

Pemahaman Subjek 4 terhadap soal pemecahan masalah sejalan dengan hasil soal yang dibuat.Ciri soal pemecahan masalah yang Subjek 4 kemukakan belum cukup lengkap.Sehingga Subjek 4 beranggapan setiap soal cerita adalah soal pemecahan masalah tanpa memandang ke struktur masalah yang ada dalam soal.

\section{Soal Subjek 5}

Berikut soal pemecahan masalah dan alternatif jawaban yang dibuat subjek 5

Suatu hari deni memesan minyak makan sebanyak $145 \mathrm{~L}$. lalu minyak tersebut dituangkan kedalam drum berbentuk tabung dengan jarijari $30 \mathrm{~cm}$. berapakah ketinggian minyak makan dalam drum tersebut?

Penyelesaian:

Dit : Volume $=145$ Liter

$$
\begin{aligned}
& =145.000 \mathrm{~cm}^{3} \\
\text { Jari-jari } & =30 \mathrm{~cm}
\end{aligned}
$$

Dit $=$ t.....?

Jawab:

$$
\begin{gathered}
t=\frac{v}{\pi \times r^{2}} \\
\frac{145.000}{3,14 \times 30} \\
\frac{145.000}{2826} \\
51,30 \mathrm{~cm}
\end{gathered}
$$

Jadi ketinggian minyak makan dalam drum adalah $51,30 \mathrm{~cm}^{3}$
Secara bahasa dan penggunaan notasi soal yang dibuat oleh subjek 5 sudah bisa dipakai untuk mengukur kemampuan mahasiswa. Namun soal yang dibuat belum berbentuk soal pemecahan masalah matematika.Struktur masalah yang diberikan soal masih sangat sederhana.Soal tersebut lebih tepat digunakan untuk mengukur pemahaman konsep siswa terhadap volume tabung. Siswa yang memahami konsep volume tabung akan dengan mudah menyelesaikan soal tersebut.

Berdasarkan wawancara, menurut Subjek 5 soal pemecahan masalah adalah soal yang mampu menghubungkan pengetahuan masa lalu dengan masa sekarang. Selain itu, menurut subjek 5 dalam menyelesaikan soal tersebut siswa sudah memiliki pengetahuan dasar dalam menyelesaikannya namun pada saat yang sama belum bisa menyelesaikan seperti cara yang sudah diketahuinya.

Pengetahuan Subjek 5 tentang soal pemecahan masalah matematika berbanding terbalik dengan model soal yang dibuat. Hal ini membuktikan bahwa pemahaman subjek tentang teori tidak menjamin subjek tersebut mahir dalam membuat soal.

\section{Soal Subjek 6}

Berikut soal pemecahan masalah dan alternatif jawaban yang dibuat oleh subjek 6 Sebuah ember yang berukuran sedang berbentuk tabung tanpa tutup. Kemudian diletakan di dalamnya bola memiliki jari-jari 12 
cm. maka berapakah luas keseluruhandari ember yang berbentuk tabung tersebut Penyelesaian

Diketahui: jari-jari bola $12 \mathrm{~cm}$

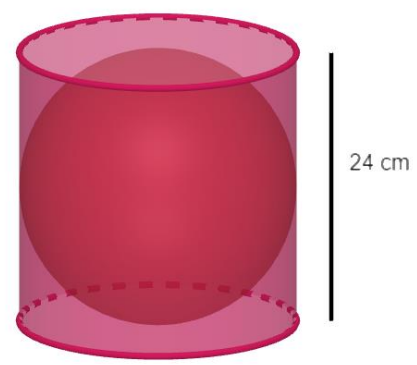

Ditanya: luas permukaan tabung Jawab:

Dari gambar di samping terlihat bahwa jari-jari alas = jari-jari bola=12 cm dan tinggi tabung adalah diameter bola, sehingga Luas permukaan tabung

$$
\begin{gathered}
=2 \pi r^{2}+(2 \pi r t) \\
=2 \pi r(r+t) \\
=2 \pi(12)(12+24) \\
=864 \pi
\end{gathered}
$$

Jadi luas permukaan tabung adalah $864 \pi$

Bahasa soal yang dibuat oleh subjek 6 sudah sesuai stadar bahasa yang bagus namun informasi yang disampaikan tidak lengkap untuk diselesaikan.Berdasarkan jawaban yang dibuat oleh Subjek 6, informasi yang tidak disampaikan adalah permukaan bola menyentuh dinding, alas dan atap ember.Jadi soal yang dibuat oleh Subjek 6 tidak bisa dipakai. Ketika hal ini dikonfirmasi melalui wawancara, subjek membenarkan bahwa informasi soal tersebut tidak lengkap, namun karena soal tersebut dibuat oleh subjek maka bisa dijawab sesuai asumsi subjek pada soal.

Sementara itu, berdasarkan wawancara pemahaman Subjek 6 terhadap pemecahan masalah matematika masih minim.Subjek hanya memahami bahwa soal pemecahan masalah adalah soal berbentuk cerita kehidupan sehari-hari tanpa memperhatikan struktur masalah yang ada pada soal.

Berdasarkan soal yang dibuat oleh ke-6 subjek yang mengumpulkan soal hanya dua soal yang berkategoti soal pemecahan masalah yaitu sola yang dibuat oleh subjek 1 dan subjek 3.Sedangkan soal yang dibuat oleh subjek 2, subjek 4 dan subjek 5 masih berbentuk soal pemahaman konsep.Sementara soal yang dibuat oleh subjek 6 tidak bisa digunakan karena informasi soal yang tidak lengkap.

Namun, pemahaman subjek terhadap teori soal pemecahan masalah cukup bagus.Berdasarkan wawancara semua subjek memahami bahwa soal pemecahan masalah dapat berbentuk soal cerita. Holmes mengungkapkan bahwa pemecahan masalah adalah proses menyelesaikan jawaban dari pertanyaan yang berbentuk cerita, teks, tugastugas-tugas dan situasi tertentuk(Fauzan, 2010). Subjek juga memahami jika soal pemecahan masalah membutuhkan pemahaman dalam menyelesaikannya, membutuhkan analisis dan tidak serta merta bisa diselesaikan hanya dengan memasukan informasi ke dalam rumus. Namun dari semua subjek tidak ada yang memahami bahwa soal pemecahan masalah bisa berbentuk soal terbuka (open ended). Hal ini juga terlihat dari soal yang dibuat semuanya berbentuk soal 
tertutup. Pada hal calon guru yang tidak dibiasakan mengembangkan soal-soal open ended kemampuan berpikir kritisnya tidak akan berkembang yang juga berimbas kepada kualitasnya nanti ketika menjadi guru(Kurniasih, 2016).

\section{SIMPULAN DAN SARAN}

\section{Simpulan}

Berdasarkan hasil penelitian dapat disimpulkan bahwa subjek secara umum sudah memahami teori soal pemecahan masalah matematika.Akan tetapi pemahaman subjek terhadap pemecahan masalah tidak selalu berbanding lurus dengan kemampuan subjek dalam membuat soal pemecahan masalah.

\section{Saran}

Bagi calon guru yang sudah mempelajari teori-teori tentang kemampuan belajar matematika disarankan untuk berlatih membuat soal untuk mengukur kemampuan tersebut. Sementara itu, peneliti lain disarankan untuk menganalisis kemampuan calon guru dalam membuat berbagai soal untuk mengukur kemampuan yang lain seperti soal penalaran, komunikasi, koneksi dan representasisehingga didapatkan temuan sebagai dasar untuk meningkatkan kemampuan calon guru.

\section{REFERENSI}

Bell, F. (1978). Teaching and Learning Mathematics: In Secondary Schools
(Second Pri). Wm. C. Brown. Company.

Cahyani, H., \& Setyawati, R. W. (2016).

Pentingnya Peningkatan Kemampuan

Pemecahan Masalah melalui PBL untuk Mempersiapkan Generasi Unggul Menghadapi MEA. Seminar Nasional Matematika X Universitas Negeri Semarang, 151-160.

Chapman, O. (2015). Mathematics Teachers' Knowladge for Teaching Problem Solving. Lumat, 3(1), 19-36.

Demirel, M., Derman, I., \& Karagedik, E. (2015). A study on the relationship between reflective thinking skills towards problem solving and attitudes towards mathematics. Procedia - Social and Behavioral Sciences, 197(February), 20862096.

https://doi.org/10.1016/j.sbspro.2015.07.32 6

Fauzan, A. (2010). Modul PPG Assesmen Berbasis Kelas Dalam Pembelajaran Matematika. FMIPA UNP.

Febrilia, B. R. A. (2019). Profil Kemampuan Guru Dalam Merancang Soal/Permasalahan Matematika Ditinjau Dari Taksonomi Bloom. Jurnal Pendidikan Matematika Indonesia, 4(2), 73-78.

Hamzah, A. (2019). Metode Penelitian Kualitatif. Literasi Nusantara.

Hidayah, N., Suyitno, H., \& Juneidi, I. (2014). Analisis Kemampuan Guru Matematika Smp Dalam Membuat Soal-Soal Pemecahan Masalah. Unes Journal of Mathematics Education Researcs, 3(1).

Kemendikbud RI. (2020). Laporan Hasil Ujian Nasional 2019. Kemendikbud RI.

Kurniasih, A. W. (2016). Budaya Mengembangkan Soal Cerita Kontekstual Open-Ended Mahasiswa Calon Guru Matematika untuk Meningkatkan Berpikir 
Kritis. Prosiding Seminar Nasional

MatematikaSeminar Nasional Matematika, 5, 9-17.

Kurniawan, Y. (2016). Peningkatan Kemampuan Pemecahan Masalah Matematis Siswa melalui Pembelajaran Berbasis Masalah. Jurnal Penelitian Pendidikan Dan Pengajaran Matematika, 2(1), 75-86.

Lestari, H., Fitriza, R., \& A, H. (2020). Pengaruh Kecemasan Matematika (Mathematics Anxiety) terhadap Kemampuan Pemecahan Masalah Peserta Didik Kelas VII Mts. Math Educa, 4(1).

Lestari, L., \& Sofyan, D. (2014). Perbandingan Kemampuan Pemecahan Masalah Siswa dalam Matematika Antara Yang Mendapat Pembelajaran Matematika Realistik (PMR) dengan Pembelajaran Konvensional. Mosharafa, 3, 95-108.

Lutfianto, M., Zulkardi, \& Hartono, Y. (2012). Unfinished Student Answer In Pisa Mathematics Contextual Problem. Journal on Mathematics Education, 4(2).

Mullis, I. V. S., Martin, M. O., Foy, P., \& Hooper, M. (2015). TIMSS 2015 International Results in Mathematics.

NCTM. (2000). Principles and Standards for School Mathematics. The National Council of Teachers of Mathematics, Inc.

Ningsih, R. S., \& Purwasih, R. (2017). Pembelajaran Problem Based Learning Untuk Meningkatkan Kemampuan Pemecahan Masalah Matematis Dan Self Efficacy Mahasiswa Calon Guru. Jurnal Nasional Pendidikan Matematika, 1(1).

Oktaviyanthi, R., \& Agus, R. N. (2018). Peningkatan kemampuan pemecahan masalah mahasiswa calon guru melalui keterampilan fungsional matematis. Beta Jurnal Tadris Matematika, 11(1).
Permendikbud. (2014). Peraturan Menteri Pendidikan dan Kebudayaan Republik Indonesia Nomor 103 Tahun 2014 Tentang Pembelajaran pada Pendidikan Dasar dan Menengah.

Polya, G. (1973). How to Solve It. Princeton University Press.

Purnomo, E. A., \& Mawarsari, V. D. (2014). Pembelajaran Problem Based Learning Untuk Meningkatkan Kemampuan Pemecahan Masalah Matematis Dan Self Efficacy Mahasiswa Calon Guru. Jurnal Karya Pendidikan Matematika, 1(1).

Reiss, K., \& Törner, G. (2007). Problem solving in the mathematics classroom: The German perspective. ZDM - International Journal on Mathematics Education, 39(56), 431-441. https://doi.org/10.1007/s11858007-0040-5

Samo, D. D. (2017). Kemampuan Pemecahan Masalah Mahasiswa Tahun Pertama pada Masalah Geometri Konteks Budaya. Jurnal Riset Pendidikan Matematika, 4(2), 141152.

Schleicher, A. (2018). PISA 2018 Insights and Interpretations.

Schoenfeld, A. H. (1987). Polya, Problem Solving, and Education. Mathematic Magazine, 60(5), 283-291. https://doi.org/10.2307/2972154

Schunk, D. H. (2012). Learning Teoris (Terjemahan oleh Eva Hamidah,dkk). Pustaka Pelajar.

Siswono, T. Y. E. (2018). Pembelajaran Matematika. Rosda Karya.

Suherman dkk, E. (2002). Startegi Pembelajaran Matematika Komtemporer. UPI.

Wardani, S., Setiawan, B., \& Hastuti, S. (n.d.). Analisis Kesalahan Berbahasa pada Soal 
Ujian Pelajaran Bahasa Indonesia.

Basastra, 8(April 2020), 180-194.

Youngchim, P., Pasiphol, S., \& Sujiva, S. (2015). Development of a Mathematical Problem Solving Diagnostic Method: An Application of Bayesian Networks and
Multidimensional item Respond Theory. Procedia - Social and Behavioral Sciences, 191, 742-747.

https://doi.org/https://doi.org/10.1016/j.sbs pro.2015.04.497 